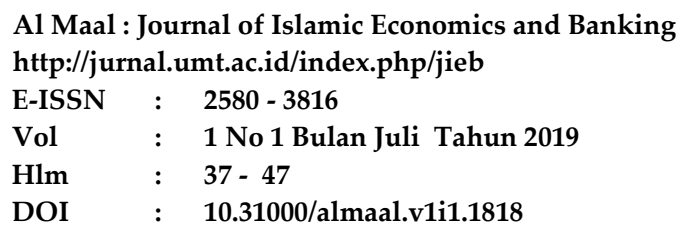

\title{
Pengaruh Pembiayaan Ijarah Dan Biaya Operasional Pendapatan Terhadap Profitabilitas Bank Syariah Mandiri
}

\author{
Sabik Khumaini 1,*, Nurul Fathiya Armina ${ }^{2}$ \\ ${ }^{1,2}$ Prodi Perbankan Syariah, Universitas Muhammadiyah Tangerang, Tangerang, \\ Indonesia \\ *Email : sabik81@gmail.com,
}

\begin{abstract}
This study was conducted to examine the effect of Ijarah financing variables and Operational Income Operational Costs (BOPO) on the profitability of ROA (Return on Assets) at Bank Syariah Mandiri. The analysis technique used is multiple regression analysis and hypothesis testing using partial $t$ test, $F$ test simultaneously with a significance level of $5 \%$ and the coefficient of determination test. In addition, classical tests are also carried out which include the normality test, the heteroscedasticity test, the autocorrelation test and the multicollinearity test. The conclusions obtained are based on the results of the calculated hypothesis testing, showing the variable Ijarah and BOPO significantly negative effect on Return on Assets (ROA) in the period 2006-2015. Meanwhile, the results of the statistical F test, the independent variables Ijarah and $B O P O$ together have a significant effect on the dependent variable ROA with a probability value of less than 0.05. The predictive ability of the two variables on ROA is $24.7 \%$. While the remaining $75.3 \%$ was accepted by other factors outside the regression model.
\end{abstract}

Keywords: Financing; Ijarah; Revenue; Profitability

\begin{abstract}
ABSTRAK
Penelitian ini dilakukan untuk menguji pengaruh variabel pembiayaan Ijarah dan Biaya Operasional Pendapatan Operasional (BOPO) terhadap profitabilitas ROA (Return on Asset) di Bank Syariah Mandiri. Teknik analisis yang digunakan adalah analisis regresi berganda dan uji hipotesis menggunakan uji $t$ secara parsial, uji F secara simultan dengan level of significance $5 \%$ dan uji koefisien determinasi. Selain itu juga dilakukan uji asumsi klasik yang meliputi uji normalitas, uji heteroskedastisitas, uji autokorelasi dan uji multikolinieritas. Kesimpulan yang diperoleh yaitu berdasarkan hasil uji hipotesis thitung, menunjukkan bahwa variabel Ijarah dan BOPO berpengaruh signifikan negatif terhadap Return on Asset (ROA) pada periode 2006-2015. Sedangkan secara simultan berdasarkan hasil uji statistik $F$, variabel independen Ijarah dan BOPO secara bersama-sama berpengaruh signifikan terhadap variabel dependen ROA dengan nilai probabilitas kurang dari 0.05. Kemampuan prediksi dari kedua variabel tersebut terhadap ROA sebesar $24.7 \%$. Sedangkan sisanya $75.3 \%$ dijelaskan oleh faktor lain di luar model regresi.
\end{abstract}

Kata kunci: Pembiayaan; Ijarah; Pendapatan; Profitabilitas 


\section{Pendahuluan}

Bank adalah lembaga keuangan yang kegiatan usahanya adalah menghimpun dana dari masyarakat dan menyalurkan kembali dana tersebut ke masyarakat serta memberikan jasa-jasa lainnya. Ada dua sistem perbankan yang berkembang di Indonesia, yaitu Bank Konvensional dan Bank Syariah. Perbedaan mendasar mengenai dua sistem tersebut adalah Bank Konvensional menggunakan sistem bunga dalam membagi keuntungan. Sedangkan Bank Syariah menggunakan sistem nisbah (bagi hasil) dalam membagi keuntungan antara bank dan nasabah. Sementara itu, negara Indonesia yang mayoritas penduduknya adalah muslim sangat membutuhkan adanya Bank Syariah (Kasmir, 2008).

Bank Syariah memiliki berbagai macam produk pembiayaan, simpanan dan tabungan. Produk pembiayaan salahsatunya adalah pembiayaan ijarah. Ijarah adalah akad pemindahan hak guna atas barang atau jasa melalui pembayaran upah sewa, tanpa diikuti dengan pemindahan kepemilikan atas objek atau barang itu sendiri. Pembiayaan ijarah merupakan pembiayaan yang diberikan oleh Bank Syariah Mandiri untuk dapat memberikan solusi kepada nasabah yang membutuhkan pembiayaan. Namun, banyak masyarakat yang belum mengetahui mengenai pembiayaan Ijarah. Oleh karena itu dibutuhkan sosialisasi yang lebih menyeluruh kepada masyarakat. Di Bank Syariah Mandiri, akad tersebut dipakai dalam pembiayaan Edukasi BSM dan pembiayaan kepada pensiunan (Firdaus, 2005).

BOPO menurut kamus keuangan adalah kelompok rasio yang mengukur efisiensi dan efektivitas operasional suatu perusahaan dengan jalur membandingkan satu terhadap lainnya. Berbagai angka pendapatan dan pengeluaran dari laporan laba rugi dan terhadap angka-angka dalam neraca. Rasio biaya operasional adalah perbandingan antara biaya operasional dan pendapatan operasional. Dimana jika pendapatan lebih besar dari biaya operasional, maka bank akan mendapatkan keuntungan yang lebih besar (Murhadi, 2013).

Tujuan akhir yang ingin dicapai suatu perusahaan yang terpenting adalah memperoleh laba atau keuntungan yang maksimal, di samping hal-hal lainnya. Untuk mengukur tingkat keuntungan suatu perusahaan, digunakan rasio keuntungan atau rasio profitabilitas yang dikenal juga dengan nama rasio rentabilitas. Profitabilitas merupakan kemampuan yang dicapai oleh perusahaan dalam satu periode tertentu. Dasar penilaian profitabilitas adalah laporan keuangan yang terdiri dari laporan neraca dan laba/rugi perusahaan. Profitabilitas merupakan indikator yang tepat untuk mengukur kinerja suatu bank dan kemampuan bersaing. Salah satu indikator yang digunakan untuk mengukur tingkat profitabilitas adalah melalui Return on Asset (ROA) atau rasio laba terhadap asset (Kasmir, 2015).

Profitabilitas adalah ukuran spesifik dari performa sebuah bank, dimana ia merupakan tujuan dari manajemen perusahaan dengan memaksimalkan nilai dari para pemegang saham, optimalisasi dari berbagai tingkat return dan minimalisasi resiko yang ada. Tujuan analisis profitabilitas sebuah bank adalah untuk mengukur tingkat efisiensi usaha dan profitabilitas yang dicapai oleh bank yang bersangkutan. Pembiayaan merupakan salah satu faktor yang mempengaruhi profitabilitas Bank Syariah, termasuk pembiayaan ijarah. Biaya Operasional dan Pendapatan Operasional pun mampu mempengaruhi profitabilitas Bank Syariah. 


\section{KAJIAN LITERATUR}

Ijarah merupakan salah satu bentuk kegiatan muamalah dalam memenuhi keperluan hidup manusia, seperti sewa-menyewa, kontrak atau menjual jasa perhotelan dan lain-lain. Menurut fatwa DSN-MUI No. 09/DSN-MUI/IV/2000 tanggal 13 April 2000 tentang pembiayaan Ijarah, yang dimaksudkan dalam ijarah adalah pemindahan hak pakai atas suatu barang atau jasa dalam waktu tertentu melalui pembayaran sewa atau upah, tanpa diikuti dengan pemindahan kepemilikan barang itu sendiri (Haroen, 2007).

Definisi akad Ijarah adalah akad pemindahan hak guna atas barang atau jasa melalui pembayaran upah sewa, tanpa diikuti dengan pemindahan kepemilikan (ownership / milkiyyah) atas barang itu sendiri. Pembiayaan ijarah adalah penyediaan dana atau tagihan yang berupa transaksi sewa dalam bentuk akad ijarah dengan opsi perpindahan hak kepemilikan dengan akad Ijarah Muntahiya Bit Tamlik (IMBT) berdasarkan persetujuan atau kesepakatan antara bank dengan nasabah pembiayaan sebagai pihak yang diwajibkan untuk melunasi utang atau kewajiban sewa sesuai akad (Firdaus, 2005).

Ijarah adalah suatu lease contract di bawah suatu bank atau lembaga keuangan yang menyewakan peralatan (equipment), sebuah bangunan, barang-barang seperti mesin-mesin, pesawat terbang dan lain-lain kepada salah satu nasabahnya berdasarkan pembebanan biaya sewa yang sudah ditentukan sebelumnya secara pasti (fixes charge). Dengan demikian, dalam ijarah tidak hanya barang yang dapat dijadikan objek ijarah tetapi juga jasa. Selain itu tidak terjadi perubahan kepemilikan atas objek ijarah, tetapi hanya terjadi perpindahan hak pakai dari pemilik yang menyewakan barang atau jasa kepada penyewa. Dalam transaksi ijarah, bank adalah pihak yang menyewakan dan nasabah adalah penyewa (Sjahdeini, 2014).

Biaya atau beban (expenses) adalah penurunan manfaat ekonomi selama suatu periode akuntansi dalam bentuk arus keluar atau berkurangnya aset atau terjadinya kewajiban yang mengakibatkan penurunan ekuitas yang tidak menyangkut pembagian kepada penanam modal. Biaya operasi (operating expense) merupakan biaya yang terkait dengan operasional perusahaan yang meliputi biaya penjualan dan administrasi (selling and administrative expense), biaya iklan (advertising expense), biaya penyusutan (depreciation and amortization expense) serta biaya perbaikan dan pemeliharaan (repairs and maintenance expense). Beban (expense) adalah biaya yang secara langsung atau tidak langsung telah dimanfaatkan di dalam usaha menghasilkan pendapatan dalam suatu periode atau yang sudah tidak memberikan manfaat ekonomis untuk kegiatan masa berikutnya (Muhammad, 2008).

Pendapatan/pengahasilan (revenue) adalah peningkatan jumlah harta atau penurunan kewajiban suatu badan usaha yang timbul dari penyerahan barang dagang atau jasa atau pun aktivitas usaha lainnya di dalam suatu periode. Penghasilan (income) adalah kenaikan manfaat ekonomi selama suatu periode akuntansi dalam bentuk pemasukan atau penambahan aset atau penurunan kewajiban yang mengakibatkan kenaikan ekuitas yang tidak berasal dari kontribusi penanam modal. Pendapatan/penjualan bersih (net revenue atau net sales) diperoleh dari total pendapatan/penjualan selama satu periode dikurangi dengan pembatalan penjualan (sales return) dan pengurangan dari harga dari harga yang tercantum dalam faktur asli karena masalah tertentu seperti kerusakan, kuantitas yang tidak tepat ataupun kualitas yang buruk (Priatna, 2011). 
Rasio Biaya Operasional Pendapatan Operasional (BOPO) yaitu perbandingan antara beban operasional dengan pendapatan operasional. Rasio yang sering disebut rasio efisiensi ini digunakan untuk mengukur kemampuan manajemen bank dalam mengendalikan biaya operasional terhadap pendapatan operasional. Akun Biaya Operasional Pendapatan Operasional (BOPO) berada pada laporan keuangan laba/rugi. Laporan laba/rugi (income statements) adalah laporan yang menggambarkan kinerja hasil operasional perusahaan selama periode tertentu (Murhadi, 2013).

Profitabilitas atau rasio profitabilitas merupakan rasio untuk menilai kemampuan perusahaan dalam mencari keuntungan. Atau kemampuan kemungkinan untuk mendatangkan keuntungan (memperoleh laba). Pengertian lain dari profitabilitas adalah kemampuan perusahaan untuk memperoleh keuntungan dari usahanya. Rasio ini juga memberikan ukuran tingkat efektivitas manajemen suatu perusahaan. Hal tersebut ditunjukkan oleh laba yang dihasilkan dari penjualan dan pendapatan investasi. Dengan kata lain, penggunaan rasio ini menunjukkan efisiensi perusahaan (Sunyoto, 2013).

Rasio profitabilitas dapat dilakukan dengan menggunakan perbandingan antara berbagai komponen yang ada di laporan keuangan, terutama laporan keuangan neraca dan laporan laba rugi. Tujuan dilakukannya pengukuran adalah agar terlihat perkembangan perusahaan dalam rentang waktu tertentu, baik penurunan atau kenaikan, sekaligus mencari penyebab perubahan tersebut. Dengan memperoleh laba yang maksimal sesuai dengan target perusahaan, maka perusahaan dapat berbuat banyak bagi kesejahteraan pemilik, karyawan, serta meningkatkan mutu produk dan melakukan investasi baru sebagai menjadi tambahan bagi laba perusahaan. Oleh karena itu, manajemen perusahaan dituntut harus mampu untuk memenuhi target yang telah ditetapkan.

\section{Metode Penelitian}

\section{Sumber Data Penelitian}

Suatu penelitian memerlukan data-data yang akan membantu peniliti untuk sampai pada suatu kesimpulan tertentu, sekaligus data tersebut akan memperkuat kesimpulan yang dibuat. Data yang digunakan dalam penelitian ini merupakan data sekunder. Data yang digunakan dalam penelitian ini adalah laporan keuangan triwulan Bank Syariah Mandiri periode 2006-2015 yang datanya terdapat di Bank Syariah Mandiri dan Bank Indonesia.

\section{Metode Analisis Data Analisis Regresi Berganda}

Penelitian ini mencari pembiayaan ijarah dan biaya operasional pendapatan operasional terhadpat profitabilitas di Bank Syariah Mandiri maka analisis yang digunakan adalah regresi berganda dengan rumus sebagai berikut:

$$
\mathrm{Y}=\alpha+\beta \mathrm{X}_{1}+\beta \mathrm{X}_{2}+\mathrm{e}
$$

Dimana :

$$
\begin{array}{ll}
\mathrm{Y} & =\text { ROA } \\
\alpha & =\text { Konstanta } \\
\mathrm{X}_{1} & =\text { Ijarah } \\
\mathrm{X}_{2} & =\text { BOPO }
\end{array}
$$


$\beta=$ Koefisien Regresi Variabel Independen

e $\quad=$ Standard eror

Teknik analisis yang digunakan adalah regresi berganda dengan persamaan kuadrat terkecil dan uji hipotesis menggunakan t-statistik untuk menguji koefisien regresi parsial serta f-statistik untuk menguji keberartian pengaruh secara bersama-sama dengan level of significance 5\% (Ghozali: 2013). Selain itu juga dilakukan uji asumsi klasik yang meliputi uji normalitas, uji multikolinieritas, uji heteroskedastisitas dan uji autokorelasi.

\section{Hasil dan Pembahasan Statistik Deskripsi}

Data yang digunakan dalam penelitian ini adalah laporan keuangan triwulan Bank Syariah Mandiri periode 2006-2015 yang datanya terdapat di Bank Syariah Mandiri dan Bank Indonesia. Dari data yang telah diinput, dapat dilihat nilai maksimum, minimum, mean dan standar deviasi dari masing-masing variabel penelitian dibawah ini:

Tabel 1 Perhitungan Nilai Maksimum, Minimum, Mean, dan Standar Deviation

Descriptive Statistics

\begin{tabular}{cccccc}
\hline & $N$ & Minimum & Maximum & Mean & Std. Deviation \\
\hline ROA & 39 & -.04 & 2.56 & 1.6013 & .67110 \\
IJARAH & 39 & 1064.26 & 11191.99 & 4085.0720 & 2926.93866 \\
BOPO & 39 & 25.18 & 73.57 & 38.1181 & 10.44944 \\
Valid N (listwise) & 39 & & & & \\
\hline
\end{tabular}

Sumber: output SPSS versi 23

Berdasarkan hasil perhitungan diatas, terdapat 40 sampel laporan keuangan triwulan. Rata-rata ROA tidak menunjukkan penyimpangna data yang tinggi karena standar deviasi (SD) lebih rendah dari rata-rata (mean). Rata-rata ROA selama periode 2006-2015 sebesar 1.6013 dengan standar deviasi 0.67110. Hasil tersebut menunjukkan bahwa nilai SD lebih rendah dari rata-rata ROA yang menunjukkan bahwa data variabel ROA merupakan hasil yang baik. Hal tersebut juga terjadi pada variabel Ijarah periode 2006-2015 dengan rata-rata (mean) 4085.0720 dan standar deviasi sebesar 2926.93866. Sedangkan BOPO periode 2006-2015 dengan rata-rata (mean) sebesar 38.1181 dan standar deviasi sebesar 10.44944 .

Dari 39 sampel laporan keuangan triwulan neraca dan laba/rugi BSM (2006-2015) terlihat bahwa nilai minimum ROA adalah -0.04 yang terjadi pada triwulan ke 4 (desember) tahun 2014 dan nilai maksimum 2.56 terjadi pada triwulan ke 1 (maret) tahun 2013. Untuk variabel Ijarah, nilai minimum aktiva yang didapatkan adalah sebesar 1064.26 terjadi pada triwulan ke 1 (Maret) tahun 2006 dan nilai aktiva maksimum Ijarah sebesar 11191.99 terjadi pada triwulan ke 2 (Juni) tahun 2015. Sedangkan nilai minimum BOPO sebesar 25.18 terjadi pada triwulan ke 4 (Desember) tahun 2010 dan nilai maksimum BOPO sebesar 73.57 terjadi pada triwulan ke 3 (September) tahun 2015. 


\section{Uji Asumsi Klasik}

\section{Uji Normalitas}

Uji normalitas bertujuan untuk menguji apakah dalam model regresi, variabel pengganggu atau residual memiliki distribusi normal. Uji normalitas yang dipergunakan adalah analisis grafik yang merupakan salah satu cara termudah untuk melihat normalitas residual dengan melihat grafik histogram, membandingkan antara data observasi dengan distribusi yang mendekati distribusi normal.

Tabel 2 Uji Normalitas

One-Sample Kolmogorov-Smirnov Test

\begin{tabular}{ccc}
\hline & & \multicolumn{2}{c}{ Unstandardized Residual } \\
\hline Normal Parameters ${ }^{a, b}$ & Mean & 39 \\
& Std. Deviation & .0000000 \\
Most Extreme Differences & Absolute & .37625110 \\
& Positive & .123 \\
& Negative & .098 \\
Test Statistic & -.123 \\
Asymp. Sig. (2-tailed) & .123 \\
a. Test distribution is Normal. & $.243^{c}$ \\
b. Calculated from data. & \\
c. Lilliefors Significance Correction. & \\
Sumber: output SPSS versi 23
\end{tabular}

Hasil sampel pada table 2 menunjukkan bahwa tes statistik nilai Kolmogorov Smirnov sebesar 0,123 dan tingkat signifikan pada 0.243 (karena $\mathrm{p}=0.143>$ dari 0,05 ) maka dapat disimpulkan bahwa nilai residual berdistribusi normal.

Gambar 1. Uji Normalitas dengan Grafik P-P Plot

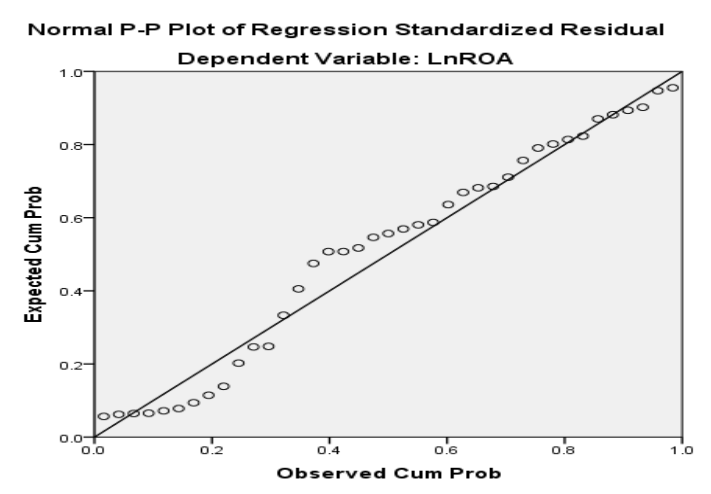


Pada gambar 1 dapat dilihat bahwa hasil grafik uji normalitas menggunakan p-p plot data atau titik menyebar disekitar garis diagonal dan mengikuti arah garis diagonal data dikatakan berdistribusi normal.

\section{Uji Autokorelasi}

Penyimpangan autokorelasi dalam penelitian ini diuji dengan uji Durbin - Watson (DW-test). Hasil regresi dengan tingkat signifikan $0,05(\alpha=0.05)$ dengan sejumlah variabel independen 2 dan banyak data $(\mathrm{n}=39)$. Berikut ini adalah hasil dari uji autokorelasi DW-test:

Tabel 3 Uji Autokorelasi

\begin{tabular}{|c|c|c|c|c|c|}
\hline \multicolumn{6}{|c|}{ Model Summary } \\
\hline \multirow[b]{2}{*}{ Model } & \multirow[b]{2}{*}{$R$} & \multicolumn{2}{|r|}{ Adjusted $R$} & Std. Error of the & \multirow[b]{2}{*}{ Durbin-Watson } \\
\hline & & $R$ Square & Square & Estimate & \\
\hline 1 & $.537^{a}$ & .289 & .247 & .25168 & 2.204 \\
\hline \multicolumn{6}{|c|}{ a. Predictors: (Constant), BOPO, IJARAH } \\
\hline \multicolumn{6}{|c|}{ b. Dependent Variable: ROA } \\
\hline \multicolumn{6}{|c|}{ Sumber: output SPSS versi 23} \\
\hline
\end{tabular}

Berdasarkan hasil uji Durbin-Watson, didapat nilai DW sebesar 2.204. Sedangkan dalam tabel DW untuk $\mathrm{k}=2$ dan $\mathrm{N}=39$, besar DW-tabel dl (batas luar) $=1.382 \mathrm{dan} \mathrm{du}$ (batas dalam $)=1.597$. Oleh karena DW 2,204 lebih besar dari $d u$ (batas atas), maka uji Durbin-Watson (DW-test) dapat disimpulkan tidak terdapat autokorelasi antar residual.

\section{Uji Multikolonieritas}

Cara mendeteksi ada atau tidaknya multikolonieritas dalam model regresi menggunakan nilai variance inflation factor (VIF). VIF dapat menunjukkan setiap variabel independen manakah yang dijelaskan oleh variabel independen lainnya. Maka besarnya VIF dari dua variabel independen yang digunakan (ROA, Ijarah, BOPO) ditunjukkan melalui output SPSS berikut ini:

Tabel 4 Uji Multikolinieritas

\begin{tabular}{|c|c|c|c|c|c|c|c|c|}
\hline \multicolumn{9}{|c|}{ Coefficients $^{a}$} \\
\hline \multirow{6}{*}{1} & & Unstc & dardized & Standardized & & & & \\
\hline & & $\mathrm{Co}$ & icients & Coefficients & & & Collinearit & tatistics \\
\hline & Model & $B$ & Std. Error & Beta & $t$ & Sig. & Tolerance & $V I F$ \\
\hline & (Constant) & 5.318 & 1.004 & & 5.295 & .000 & & \\
\hline & $J A R A H$ & -.210 & .155 & -.245 & -1.355 & .184 & .508 & 1.968 \\
\hline & ВOРО & -.893 & .370 & -.437 & -2.414 & .021 & .508 & 1.968 \\
\hline
\end{tabular}

a. Dependent Variable:ROA

Sumber: output SPSS versi 23 
Hasil dari nilai VIF menunjukkan bahwa kedua variabel independen tidak terjadi multikolonieritas. Karena nilai VIF $<10$ dan nilai Tolerance $>0.10$. Nilai tolerance semua variabel (IJARAH dan BOPO) di atas 0,10. Sedangkan nilai VIF dari IJARAH dan BOPO kurang dari 10. Dengan demikian, variabel IJARAH dan BOPO sebagai dua variabel independen dapat digunakan untuk memprediksi ROA.

\section{Uji Heterokedastisitas}

Cara untuk mendeteksi ada atau tidaknya heteroskedastisitas adalah dengan melihat grafik plot antara nilai prediksi variabel terikat (dependen). Deteksi ada tidaknya heteroskedastisitas dapat dilakukan dengan melihat ada tidaknya pola tertentu pada grafik scatterplot. Titik-titik yang terbentuk harus menyebar secara acak dan tersebar baik di atas maupun di bawah angka 0 pada sumbu Y. Berikut ini adalah hasil uji heteroskedastisitas yang dapat dilihat melalui grafik scatterplot.

Gambar 2 Uji Heteroskedastisitas

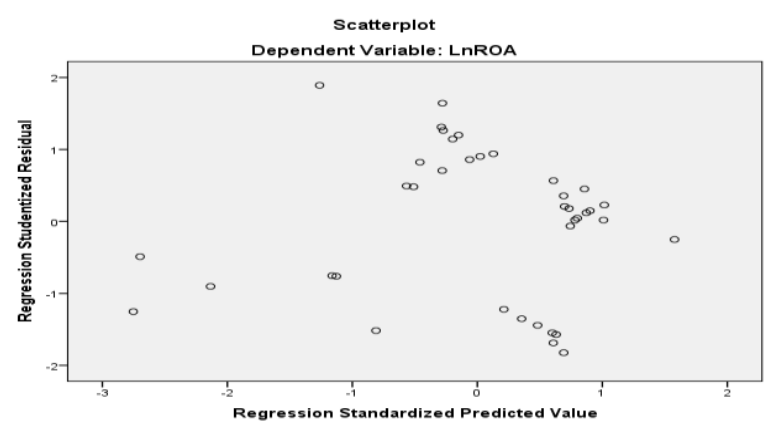

Sumber: output SPSS versi 23

Berdasarkan gambar 2 di atas maka dapat disimpulkan bahwa plot menyebar secara acak di atas maupun di bawah angka 0 pada sumbu regression studentized residual. Oleh karena itu pada model regresi yang di bentuk dinyatakan tidak terjadi gejala heterokedastisitas.

\section{Koefisien Determinasi $\left(\mathbf{R}^{2}\right)$}

Koefisien determinasi $\left(\mathrm{R}^{2}\right)$ merupakan besarnya kontribusi variabel independen terhadap variabel dependen. Semakin tinggi koefisien determinasi, semakin tinggi kemampuan variabel indepeneden dalam menjelaskan variasi perubahan pada variabel dependen. Koefisien determinasi memiliki kelemahan, yaitu bias terhadap jumlah variabel independen yang dimasukkan dalam model regresi, di mana setiap penambahan satu variabel independen dan pengamatan dalam model akan meningkatkan $\mathrm{R}^{2}$ meskipun variabel yang dimasukan tersebut tidak memiliki pengaruh yang signifikan terhadap variabel dependen. Untuk mengurangi kesalahan tersebut maka digunakan koefisien determinasi yang disesuaikan, adjusted $R$ square (adjusted $\mathrm{R}^{2}$ ). Berikut adalah hasi uji adjusted $R$ square: 
Tabel 5 Koefisien Determinasi

\begin{tabular}{ccccc}
\hline \multicolumn{4}{c}{ Model Summary $^{b}$} \\
\hline Model & $R$ & $R$ Square & Adjusted $R$ & Std. Error of the \\
1 & $.537^{a}$ & .289 & .247 & Estimate \\
& \multicolumn{3}{c}{ a. Predictors: (Constant), BOPO, JARAH } \\
\hline
\end{tabular}

b. Dependent Variable: LROA

Sumber: output SPSS versi 23

Berdasarkan tabel diatas, nilai koefisien Determinasi (adjusted $\mathrm{R}^{2}$ ) sebesar 0.247 atau $24.7 \%$. Artinya hanya $24.7 \%$ variasi ROA dapat dijelaskan oleh variasi dari dua variabel independen (IJARAH dan BOPO). Sedangkan sisanya $(100 \%-24,7 \%=75.3 \%)$ dijelaskan oleh faktor lain di luar model regresi.

\section{Uji Statistik F}

Uji statistik F untuk menguji adakah pengaruh secara bersama- sama dua variabel independen (IJARAH dan BOPO) terhadap ROA. Berikut ini adalah hasil dari SPSS:

Tabel 6 Perhitungan Regresi Simultan

\begin{tabular}{ccccccc}
\hline \multicolumn{6}{c}{ ANOVA $^{a}$} \\
\hline \multirow{4}{*}{1} & Model & Sum of Squares & $d f$ & Mean Square & $F$ & Sig. \\
& Regression & .874 & 2 & .437 & 6.902 & $.003^{b}$ \\
& Residual & 2.154 & 34 & .063 & & \\
& Total & 3.028 & 36 & & & \\
\hline
\end{tabular}

a. Dependent Variable: ROA

b. Predictors: (Constant), BOPO, JARAH

Sumber: output SPSS versi 23

Berdasarkan tabel 6 bahwa nilai F hitung sebesar 6.902 dengan probabilitas 0.003 . Karena nilai probabilitas lebih kecil dari 0.05 , maka model regresi dapat digunakan untuk memprediksi ROA atau dapat dikatakan bahwa IJARAH dan BOPO secara bersama-sama berpengaruh terhadap ROA.

\section{Uji Statistik t}

Uji statistik t menunjukkan seberapa jauh pengaruh satu variabel penjelas/independen secara individual salam menerangkan variasi variabel dependen. Hasil SPSS sebagai berikut: 
Tabel 7 Perhitungan Regresi Parsial

\begin{tabular}{|c|c|c|c|c|c|c|c|c|}
\hline \multicolumn{9}{|c|}{ Coefficientsa } \\
\hline \multirow{6}{*}{1} & & Unstc & dardized & Standardized & & & & \\
\hline & & $\mathrm{Co}$ & icients & Coefficients & & & Collinearit & Statistics \\
\hline & Model & $B$ & Std. Error & Beta & $t$ & Sig. & Tolerance & $V I F$ \\
\hline & (Constant) & 5.318 & 1.004 & & 5.295 & .000 & & \\
\hline & $J A R A H$ & -.210 & .155 & -.245 & -1.355 & .184 & .508 & 1.968 \\
\hline & ВOPO & -.893 & .370 & -.437 & -2.414 & .021 & .508 & 1.968 \\
\hline
\end{tabular}

a. Dependent Variable:ROA

Sumber: output SPSS versi 23

Dari hasil analisis regresi linier berganda dengan program SPSS seperti tabel di atas, maka persamaan regresi linier berganda yang terbentuk adalah:

$\mathrm{ROA}=1.680+(-0.410) \mathrm{IJARAH}+(-0.603) \mathrm{BOPO}$ berikut:

Dari persamaan regresi linier berganda di atas maka dapat dianalisis sebagai

Konstanta sebesar 1.680 menyatakan bahwa jika variabel independen dianggap konstan, maka nilai ROA sebesar 1.680 .

Dari hasil perhitungan, diperoleh nilai t hitung sebesar -2.046 dan nilai signifikan sebesar 0,049, maka hipotesis diterima ini berarti terdapat pengaruh signifikan antara variabel Ijarah terhadap perubahan variabel ROA. Perubahan variabel Ijarah mempunyai nilai koefisien regresi sebesar -0.410 . Koefisien bertanda negatif, berarti bahwa setiap kenaikan/penambahan nilai aktiva Ijarah sebesar $1 \%$ akan mengakibatkan penurunan rasio ROA Bank Syariah Mandiri sebesar $-0.410 \%$.

Dari hasil perhitungan, diperoleh nilai t hitung sebesar -2.093 dan nilai signifikan sebesar 0,044, maka hipotesis diterima ini berarti terdapat pengaruh signifikan antara variabel BOPO terhadap perubahan variabel ROA. Perubahan variabel BOPO mempunyai nilai koefisien regresi sebesar -0.603 . Koefisien bertanda negatif, berarti bahwa setiap kenaikan/penambahan nilai BOPO sebesar $1 \%$ akan mengakibatkan penurunan rasio ROA Bank Syariah Mandiri sebesar $-0.603 \%$.

\section{KESIMPULAN}

Berdasarkan hasil analisis data dan pembahasan yang telah diuraikan maka dapat disimpulkan bahwa data yang dipergunakan dalam penelitian ini terdistribusi normal, tidak terdapat multikolinieritas, bebas autokorelasi dan heteroskedastisitas.

Berdasarkan uji koefisien Determinasi (adjusted $\mathrm{R}^{2}$ ) sebesar 0.247 atau 24.7\%. Artinya hanya $24.7 \%$ variasi ROA dapat dijelaskan oleh variasi dari dua variabel independen (IJARAH dan BOPO). Sedangkan sisanya $(100 \%-24,7 \%=75.3 \%$ ) dijelaskan oleh faktor lain di luar model regresi. Berdasarkan hasil uji hipotesis thitung, menunjukkan bahwa variabel Ijarah berpengaruh signifikan negatif terhadap Return on Asset (ROA). Dimana nilai signifikan 0.049 lebih kecil dari 0.05 dan nilai t hitung sebesar 
-2.046. Berdasarkan hasil uji hipotesis t hitung, menunjukkan bahwa variabel Biaya Operasional Pendapatan Operasional (BOPO) berpengaruh signifikan negatif terhadap Return on Asset (ROA). Dimana nilai signifikan 0.044 lebih kecil dari 0.05 dan nilai $\mathrm{t}$ hitung sebesar -2.093 .

Berdasarkan data-data yang telah penulis amati, dalam tiga tahun terahir profitabilitas ROA mengalami penurunan. Begitu pula dengan aktiva ijarah yang mengalami nilai yang tidak stabil (fluktuatif). Oleh karena itu perlu adanya inovasi dan sosialisasi kepada masyarakat mengenai produk-produk Bank Syariah Mandiri. Terutama pada pembiayaan Ijarah dan efisiensi pada biaya operasional yang harus bisa dikendalikan agar nilainya tidak melebihi nilai pendapatan operasional. Tidak hanya Bank Syariah yang mendapatkan keuntungan, namun dapat juga meningkatkan nilai aset ekonomi syariah.

\section{REFERENSI}

Firdaus, Muhammad, et.all. 2005. Cara Mudah Memahami Akad-akad Syariah. Renaisan Jakarta.

Ghozali, Imam. 2013. Aplikasi Analisis Multivariate dengan Program SPSS 21. Badan Penerbit Universitas Diponegoro, Semarang.

Haroen, Nasrun. 2007. Fiqh Muamalah. Gaya Media Pratama, Jakarta.

Kasmir. 2015. Analisis Laporan Keuangan. Rajawali Pers, Jakarta.

Kasmir. 2008. Dasar-dasar Perbankan. Raja Grafindo Persada, Jakarta.

Muhammad, Rifki. 2008. Akuntansi Keuangan Syariah. P3EI Press, Yogyakarta.

Murhadi, Werner R. 2013. Analisis Laporan Keuangan Proyeksi dan Valuasi Saham. Salemba Empat, Jakarta.

Priatna. Ratma Budi, At all. 2011. Akuntansi Keuangan 1. Ghalia Indonesia, Bogor.

Sjahdeini, Sutan Remy. 2014. Perbankan Syariah Produk-produk dan Aspek-aspek Hukumnya. Kencana Prenadamedia Group, Jakarta.

Sunyoto, Danang. 2013. Analisis Laporan Keuangan Untuk Bisnis. CAPS, Yogyakarta. 